\title{
Atur Pasrah and Panampi in Javanese Wedding Ceremony as a Way to Preserve Harmonious Social Environment
}

\author{
Utari Listiyani ${ }^{*}$,Amirudin Amirudin \\ Master Program of Linguistics, FIB, Undip, Semarang
}

\begin{abstract}
This is a qualitative study using an ethnography of communication approach. The purpose is to analyze speech acts of atur pasrah and panampi as a part of Javanese wedding rituals,. Atur pasrah and panampi is a Javanese ritual by which the groom receives the bride's family after the wedding ceremony, and it is conducted by giving a speech from the groom through a representative of the family. This study was conducted in Mundu, Klaten, Central Java, and the data were obtained by from a video recording of a Javanese wedding ceremony downloaded from a youtube channel. In addition, we also interviewed some competent informants who are commonly involved in such a ceremony. The result of the study shows that there is discourse structure found in atur pasrah and panampi which reflects Javanese culture. Besides, some communicative acts found in the ceremony cover declarative, representative, expressive, directive, and commisive, which are bound to Javanese local wisdom. This needs to be preserved as a way to strengthen harmonious social environmnent.
\end{abstract}

Keywords: etnography, Javanese wedding, atur pasrah and panampi.

\section{Background}

Indonesia is an archipelago with a variety of languages and cultures. Each region has cultural characteristics that are always maintained and preserved by the community to keep the existence. Cultural activities that are usually carried out by the community include various activities such as weddings, death ceremonies, harvesting festival, seven monthly pregnancy events, earth charity events, and so on. In this paper, we are interested in analyzing Javanese wedding customs using the ethnography of communication approach. The purpose of ethnography of communication is to find out the patterns of communication, communicative acts, and the variety of language in a particular social events.

\footnotetext{
* Corresponding author : utarilistiyani58@gmail.com
} 
Wedding ceremony is one of the social events that have a high cultural and sacred value in one's life. In Javanese society, there are a series of events in wedding ceremonies that are still very much preserved till today. Generally, the wedding events are divided into three parts, which are the procedure before wedding, the procedure for the wedding day, and the procedure after the wedding. The procedure before wedding includes nglamar, midodareni, and siraman. Then proceed to the wedding ceremony consist of ijab qobul and panggih. The events close with ngunduh mantu, it is usually held a few day after ijab qobul.

Atur pasrah dan panampi is a process by which the groom receives the bride's family after the ceremoy. This events id conducted by giving a speech from the groom through a representative of the family.

The ritual of pasrah and panampi still exists in the end of the day and continues to be maintained by the Javanese community as a tradition that has a very high courtesy. The meaning of each speech is able to establish harmony in social life. So this is what underlines me to analyze the speech act of pasrah and panampi. I want to see how strong the meaning behind pasrah and panampi speech in the wedding event.

The purpose of the study is to identify the communicative acts in atur pasrah and panampi delivered by each family representative. This study use the theory of Searle's communication. Searle divides communication into five functions which is declarative, representative, expressive, directive, and commisive. This research is expected to contribute to ethnography and subsequent research, especially in the communicative acts of the speaker's culture. In addition, the result of the study will also be beneficial for the preservation of harmonious social environment in the global era.

\section{Literary Review}

Marriage is a legal binding between a man and a woman to live together and form a family. According to Law No. 11974 "Marriage is an inward bond between a man and a woman as husband and wife with the purpose of forming a happy and eternal family (home) based on the Supreme God" [1]. Javanese wedding ceremonies generally include, marriage, ceremony, and reception. In each of these events, there are various processes involved. In addition to the processions mentioned above, there is a procession called Manage and receive. Set resigned and the recipient is a procession that carried to accept the groom by the bride's family after the ceremony. This process is done by giving speeches from both the groom and the bride through the representatives of each family.

Ethnography of communication is a field of study that is related directly to the description and analysis of culture, and within the linguistic field of study is the description and analysis of language code [2] (Saville-Troike, 2003: 1). The focus of ethnography of communication is on the rules of communication, cultural norms and knowledge as the basis for interaction, context and content of communication, and the process of interaction. This is in line with what Hymes' comment that language cannot be separated by how and why it is used by its speakers. So there arose the theory of cultural relativism in which no culture is better or worse than another, which can evaluate a culture that is a society that has it.

The units of analysis in a communication ethnographic study include communicative situation, communicative event, and communicative act. Communicative situations are the context of communication, situations can remain the same even if the location changes, or they may change in location when different activities take place at different times. Communicative event is a fixed event defined as a whole component component. Communicative act is a communicative that occurs in an event, such as a referential statement, application, order, verbal or non-verbal [2] (Saville-Troike, 2003: 23-24).

Communicative Acts is defined as how one person acts and communicates with others. 
Communication is a linguistic performance that is part of a pragmatic study that focuses on the study of the meaning of a communication. The act of communicating is to do certain actions through words such as refusal (offer, request), thank, greet, praise, apologize, promise and complain. The forms of communication can vary from one culture to another. For example, in some cultures refusal (bid, request) can be made directly, while in other cultures it must be in certain languages before the refusal is pronounced or even without being spoken at all. This has led to misunderstandings about the meaning of speech. Chaer [3] explains that communication is the process of linguistic interaction in one or more forms of speech involving two parties, that is, the speaker or opponent of communication with one subject in a particular time, place, and situation. In a communication, the speaker usually hopes his communicative intent will be understood by the listener / opponent. Austin in Wardaugh (2015: 251) divides communication into three parts, namely, location, location, and location [4]. Locational communication is a communication device used to express something. Austin defines the resolution as "performance of saying something". The power of the illusion lies in the intent of the speaker such as the delivery of information, commands, and warnings. However, if the communication spoken by the speaker has an impact or influence on the behavior of his or her partner communicative, then this ommunication is called inhibition.

Searle (1979) classifies illocutionary acts into declarative, representative, expressive, directives, and commissive [5].

1. Declarative, which went communications intended speakers to create things (status, state, etc.). Yule (1996: 53) argues that declarative communication is a type of communication that changes the world through speech and partners communication, such as forgiving, punishing, canceling, dismissing and baptizing ${ }^{[6]}$. For example, the pronunciation of a qobul by a prospective bride causes her status to change and her prospective bride becomes a wife.

2. Representative is the communication that binds its speakers to the truth of what is being said. This type of communication is a statement, prediction, complaint, pride, acknowledgment, testimony and recommendation.

3. Expressive is the communication that the speaker intended to convey in his speech as an evaluation of what is said in the communication such as thank you, apology, and greeting congratulations. Usually, expressive sentences refer to what the speaker's feeling.

4. Directive is the act of communication that the speaker intended for the listener to perform the actions mentioned in the action such as command, prohibition, warning, propose, plead, or demand. This sentence refers more to a speaker's desire for a particular things or situation.

5. the act of communication commissive binding to implement what mentioned between interlocutors such promises, threats, offers, approve, or swear. This act of communication emphasizes the speaker's commitment to his future actions. 


\section{Research Method}

The methods used in this study are observation and interview. The method of observation was conducted by observing the rituals of pasrah and pinampi as found in a video recording from a youtube channel. In addition, to complete the data, we also used Interview method conducted with informants who have the capacity to understand the traditional Javanese wedding. Therefore, we used secondary data sources in the form of video, plus information from informants who are very helpful in completing the data while triangulating the data ${ }^{[6]}$.

In this study, data analysis was performed qualitatively by following three steps, namely data reduction, data processing, and drawing conclusion.

\section{Discussion}

One of aspects that influence the dynamics of community harmony is communication. Communication will be established when the speech partner is able to receive messages conveyed by the speaker. Speeches in pasrah and panampi contain strong meaning in consolidate communication between people. Moreover this speech is spoken in Javanese language which is reflects the gentleness of the attitude of Javanese community.

Communicative situations in this study is Javanese wedding ceremony. Communicative event that woud be analyze is focused on giving speech atur pasrah and panampi. There are three parts of discourse structure which is opening, content of speech, and closing. In atur pasrah and panampi enclose some communicative acts, they are declarative, representative, expressive, directive, and commisive. The participants who attended in that social event consist of bride and groom, their parents, and the family of each party.

This section contains discussion and analysis of data. The speech were delivered at weddings, especially in the process of giving and receiving, which was a procession handed over by the groom through his family to the bride's family. The participants in the event were mostly family members of both brides and some of the guests who were mostly of Javanese cultural background. Therefore, the language used in speech this is mostly Javanese. Since the event is a formal event, the Javanese language used is the Javanese Language Class. The analysis of the data in this section is presented as follows :

Assalamualaikum Warahmatullahi Wabarakatuh. Bismillahirahmanirrahim, wa min ayati an khalaqa lakum anfusikum azwaja litaskunu ilaiha armor alaikum dada warahmah innafi dzalika la aya qaumin yatafakkarun. Al-ayat.

Greetings along with the quotations are standard lexical used by some Javanese people. The greetings and qutations are from Arabic origin, so it is also the identity of the Javanese people who convert to Islam. With such a greeting and qutation, it is strongly shows that the wedding is taking place in the Islamic society. In atur pasrah and panampi events, all elements of the non-Muslim community are present without the presence and attributes and symbols that distinguish one another. Because Islam that is represented in terms of surrender and acceptance is more of Islam Traditional, and not a very standard Normative Islam. Traditional Islam is a synchronicity between Islam and cultural traditions, especially javanese culture. So that all those in the non-Muslim faith are in the area of tolerance to tradition. The Communication above is a Communication Act of declaration which means that the family that runs the Muslim religion and surrender.

Kawula nuwun, kepareng matur wonten ngarsanipun para pinisepuh sesepuh ingkang sampun ono ing pawawas lebdo ing pikomunikasi. Ingkang tansah kinurmatan menopo dene tuhu kinabekten, wonten ngarsanipun pangemban-pangembating nagari, sae ingkang 
tasih luamadang karyo menopo ingkang sampun purno karyo ingkang mongko dados pandam-pandaming para kawula dasih ingkang sinubeng ing pakurmatan, wonten ngarsanipun pangembating brayat agung desa Mundu nun inggih bapak kepala desa, menopo dene jajaran perangkat desa, desa Mundu ingkang winengku ing karahayon, Langkung-langkung wonten ngarsanipun kadang sinurwadi nun inggih bapak Jaka Krisnanto miwah sagung para tamu kakung menopo dene putri sedoyo ingkang manggih ing suko rahayu, kanthi trapsilo ing bekti miwah nyuwun agung ing samudra pangaksama. Sumelaning atur kulo prapdapa awit saking keparengipun rayi mas Somo Sohiman sekalian, wonten ing madyaning pisowanan kulo ingkang supados ngaturaken ush ing penggalih, kanthi hamurwane lekas wekasing kartigotining sedyo.

The expression above means an expression of respect for the parties who are presents in the wedding events. Communicative acts above belongs to expressive communication which is show how to respect audiences.

Sumonggo nun tansah kulo dherekaken manungku pujo hasta puji hastuti ingkang saestu kahunjukaken dating ngarsanipun gusti ingkang akaryo lopo, ingkang sampun paring nugroho gung kawilujengan karahmatan miwah kabagyan, ingkang menika saestu kulo lan panjenengan sedaya taksih hangantu-wantu syafaatipun junjungan kita kanjeng nabi Agung Muhammad SAW.

The expression above contains instruction given by the representative to the invited guest in praising to the God. Communicative acts above is a directive communication refers more speaker's wishes of a particular thing or situation.

Sagung para tamu kakung menopo dene putri ingkang kinurmatan, mugio kalilano kulo nggempil marak matur wonten ngarso panjenengan sedaya, mugio panjenengan sedaya kasuwun lenggah kanthi mardikaning penggalih.Wonten ngarsanipun bapak Krisnanto ingkang tuhu kinurmatan, pisowan kulo wonten ing madyaning pahargyan ingkang winengku Bapak Tugiman sekalian, ingkang sepisan kulo supados ngaturaken salam taklim kanthi kulo ikraraken "Assalamualaikum Wr. Wb." Mugi tansah hamimbuhi rahdating kayuananipun Bapak Tugiman anggenipun mangun pahargyan ing wanci siang punika.

The expressions above means expressions of respect from the bridegroom and greetings and prayers to those present at the event and in general and to the host or family of the bride. Communicative acts above are shows an expressive communication, which show respect.

Dene ingkang ongko kalih, kulo kinen hamasrahaken sekar kudup sak sele nun inggih badhe panganten kakung ingkang nama pun bagus Surawan, putra jalu saking adimas Somo Sohiman miwah genduk Sukirah, wingking saking padukuhan Tegalrejo, desa Karang Kendal, kec. Nusuk, kab. Boyolali inggih karana sampun golong gumilig ing rembag risang binargyo kakung mugio inggal kadaupno kaliyan pun roro ayu Sri Haryani putra putrinipun Bapak Tugiman sekalian ingkang pidalem wonten ing dukuh Ringinsari, desa Mundu, kec. Tulug kab. Klaten.

This phrase indicates that the groom informs the parties about the bride and groom. Communicative acts above are of representative communication in the form of statements and testimony. 
Selajengipun sowanipun rayi mas Somo Sohiman sekalian ugi hamasrahaken tata cara adat widi widono ingkang taksih sinengker wonten ing laladan Surakarto hadiningrat nun inggih ingkang kasebat abon-abon miwah paningset. Abon-abon ingkang dumados saking majemuk panjang ilang kartika kencono nun inggih gelang, kalung, menopo dene cincin, ugi hamasrahaken agemanipun penganten putri plangkah, ugi hamasrahaken redono pinangka urun bumbon pawon ingkang wilanganipun mboten kathah.

These expressions indicate that the bridegroom gives a form of appreciation in the form of gold, a ring, necklace or bracelet and money to the bride as a form of accountability to the commitment marriage. Follow-up communication as communication is a follow commissive in the form of follow-binding speaker to implement what is mentioned as promised and agreed, follow this communication focuses on the speaker's commitment to act in the future.

Ewo semanten hambok bilih kirang hanuju prono mitrat adat widi widono ingkang lumampah wonten ing padukuhan Ringinsari desa Mundu mawantu-wantu rayi mas Somo Sohiman sekalian lumantar kulo nyuwun agung ing samudera pangaksama.Selajengipun hambok bilih ing mangkeh pahargyan ingkang winengku panjenenganipu bapak Tugiman sekalian sampun keparing rampung, rayi mas Somo Sohiman sekalian menopo dene kulo sak rombongan badhe nyuwun pamit, hanamung mbok bilih anggenipun nderek hangesteni wisudan daupipun risang binargyo sarimbit, wonten tuna dungkap ing atur, kulo ingkang saestu nyuwunaken agung ing samudera pangaksama.

The communicative act above belongs to declarative communication which shows a statement.

Hambok bilih mekaten ingkang saged kulo aturaken, mestike mawon kula matur kathah kekrangan kathah kalepatan ingkang menika mawantu-wantu nyuwun agung ing samudera pangaksama. Pinangka pinutuping atur kula, ushikum wanafsi bitaqwallah wassalamualaikum warahmatullahi wabarakatuh. Nuwun.

The expression above implies an apology from the groom to the bride as a form of humility in the event of a deficiency. The acts of communication are expressive acts in the form of an apology.

I also found two unique lexicons which are only used in atur pasrah and panampi; they are abon-abon and sekar kudup sesele.abon-abon meaning a special gift given by the groom to the bride. Usually, Javanese people give gifts in the form of gold, which can be rings, bracelets, or necklaces. While sekar kudup sesele means that the bridegroom is ready to be married.

\section{Conclusion}

From this research, it was found that there are five categories of acts of ommunication, which is a declarative, representative, expressive, and commissive in a speech of atur pasrah and panampi. The communication act declarative in this speech is used to express the submission of the bridegroom. So the declarative sentence is able to transform the groom's status into part of the bride's family. The representational sentence in the speech refers to the statement to the parties, namely, the groom and the bride that the bride and groom have been officially married. Expressive sentences expressions in these speech appear as respect and apology. This is relevant because expressions of forgiveness and respect are always identified with the behavior of the Javanese in general. Then, the 
sentence directive in the speech is used by the speaker to direct the guest to what he or she says. It is more about moral commitment to God and His Messenger. The commisive sentence in this speech shows the responsibility of the speaker for what he has said. This is related to the appreciation in the form of goods and money as a form of responsibility.

\section{Reference}

[1] Saleh, K. Wantjik. A set of Rules on Marriage. Jakarta : Ghalia Indonesia (1976)

[2] Troike, Muriel Saville. “The ethnography of communication”. Oxford : Blackwell Publishing (2003)

[3] Chaer, Abdul and Agustina. Sociolingustics. Jakarta : Creative Design (2010)

[4] Wardaugh, R. An introduction to Sociolinguistics. Oxford : Blackwell Publishing (2015)

[5] Searle, Jr. Expression and meaning : Studies in the Theoryof Speech Acts. Essay Collection (Vol. 49). (1979)

[6] Yule, George. Pramatics Oxford : Oxford University Press (1996)

[7] Sudaryanto. Metode dan Teknik analisis Bahasa. Yogyakarta : Muhammadiyah University Press (1993) 